\title{
Spatial distribution of total phosphorus and organic carbon in the salt-affected soils in the Meyghan Playa, Iran
}

\section{AUTHORS}

\section{Mahboobeh Safari Sinegani ${ }^{\circledR, 1}$ safari_1365@yahoo. com}

\section{Ali Akbar Safari Sinegani ${ }^{1}$ \\ Mehrdad Hadipour $^{2}$}

@ Corresponding Author

${ }^{1}$ Soil Science

Department, Faculty of Agriculture, Bu-Ali Sina University, Hamadan, Iran.

${ }^{2}$ Faculty of Agriculture and Environmental Science, Arak University, Arak, Iran.

\begin{abstract}
Distribución espacial de fósforo total y carbono orgánico en suelos afectados por sales en Playa Meyghan, Irán

Distribuiçẫo espacial de fósforo total e carbono orgânico em solos afetados por sais em Playa Meyghan, Irão
\end{abstract}

Received: 25.11.2016 | Revised: 04.06.2017 | Accepted: 01.09.2017

\section{ABSTRACT}

Due to widespread and fast-growing urban developments, large amounts of industrial, agricultural, and municipal wastewaters are produced which can change ecosystem functions after being released into rivers and lakes. The distributions of organic carbon (OC) and total phosphorus (TP) of soil were studied in the salt affected soils in the Meyghan Playa, Iran, to show the impacts of human activities on these soils and sediment properties in this arid region of the world. Samples were taken from 250 points and were analyzed geostatistically for electrical conductivity (EC), $\mathrm{pH}, \mathrm{TP}$, and OC. Although EC had the highest coefficient of variation $(\mathrm{CV}=2.4)$ compared to $\mathrm{CV}$ s of the other soil properties, the sill/nugget ratio for EC in the geostatistical analysis was the highest one. Therefore, EC had the strongest spatial dependence compared to $\mathrm{OC}, \mathrm{TP}$, and $\mathrm{pH}$ with lower sill/nugget ratios and moderate spatial dependence. The maximum amount of $\mathrm{OC}$ was more than $2 \%$ which was observed near the entrance of municipal wastewater to the Meyghan Lake, and the highest soilTP was more than $400 \mathrm{~kg} \mathrm{mg}^{-1}$ near the entrance of municipal wastewater and also at river mouths, which can be attributed to leaching and runoff fertilizers from farmlands. Enrichment of OC in the entrance of municipal wastewater toward the lake is related to eutrophication and higher plant production.

\section{RESUMEN}

Debido a la expasión y al rápido crecimiento del desarrollo urbano, se están produciendo grandes cantidades de aguas residuales industriales, agricolas y municipales que pueden modificar las funciones ecosistémicas tras su vertido en ríos y lagos. Se estudiaron las distribuciones de carbono orgánico (OC) y fósforo total (TP) en suelos afectados por sales en Playa Meyghan, Irán, con objeto de mostrar los impactos de las actividades humanas sobre las propiedades de suelos y sedimentos en esta region árida. Se recogieron muestras en 250 puntos y se analizaron geoestadísticamente valores de conductividad eléctrica (EC), pH, TP y OC. Aunque la conductividad eléctrica presentó el coeficiente de variación más alto $(C V=2,4)$ en comparación con los coeficientes de variación de otras propiedades del suelo, la razón silll nugget para la EC en el análisis geoestadístico fue la más elevada. Por tanto, la EC presentaba la dependencia espacial más fuerte en comparación con el carbono orgánico, el fósforo total y el pH, que mostraron razones stilll nugget más bajas y una dependencia espacial moderada. La cantidad máxima de carbono orgánico fue superior al $2 \%$ y se observó en las cercanías de la entrada de aguas residuales municipales al Lago Meyghan, y el valor más elevado de fósforo total, superior a $400 \mathrm{~kg} \mathrm{mg}^{-1}$, se determinó en esta zona y también en las desembocaduras de los rios, lo que se puede atribuir a procesos de lixiviado y escorrentía con fertilizantes procedentes de las tierras de cultivo. El enriquecimiento en carbono orgánico en las cercanías de la entrada de aguas residuales municipales hacia el lago está relacionado con la eutrofización y con una mayor producción vegetal. 


\begin{abstract}
RESUMO
Devido à expansão e ao rápido crescimento e desenvolvimento urbano, têm sido produzidas grandes quantidades de águas residuais industriais, agrícolas e municipais que podem alterar, quando vertidas nos rios e lagos, as funções dos ecossistemas. Estudaram-se as distribuiçôes do carbono orgânico (OC) e do fósforo total (TP) em solos afetados por sais em Playa Meyghan, Irão, com o objetivo de mostrar os impactos das atividades humanas nas propriedades dos solos e sedimentos desta região árida. As amostras foram colbidas em 250 pontos e os valores da condutividade elétrica (EC), $\mathrm{pH}, \mathrm{TP}$ e OC foram analisados por métodos geoestatísticos. Embora a EC apresentasse o maior coeficiente de variação $(C V=2,4)$ comparada com os coeficientes de variação das outras propriedades do solo, a razão still/nugget na análise geoestatística era a mais alta. Deste modo, a EC apresentava a mais forte dependência espacial em comparação com o OC, TP e pH que mostraram razôes stillnngget mais baixas e uma dependência espacial moderada. A quantidade máxima de OC era superior a $2 \%$, a qual foi observada próximo da entrada das águas residuais municipais no Lago Mayghan, e o valor mais elevado do TP no solo, superior a $400 \mathrm{~kg} \mathrm{mg}^{-1}$, também se determinou na mesma zona e ainda nas fozes dos rios, o que se pode atribuir a processos de lixiviação e escorrência de fertilizantes provenientes das terras de cultivo. O enriquecimento em C orgânico na entrada das águas residuais municipais até ao lago está relacionado com a eutrofização e uma maior produção vegetal.
\end{abstract}

\section{Introduction}

Protection of soil quality in different ecosystems is necessary for sustainable developments, conservation of ecosystems, and diversity of species. Wetlands are important ecosystems, and they are more sensitive to anthropogenic impacts and pollution agents such as wastewater inputs from urban, industrial, and adjacent agricultural lands (Bennett et al. 2001; Ghadimi and Ghomi 2013).

The study of soil variable and responsive parameters like organic carbon (OC), phosphorus $(\mathrm{P}), \mathrm{pH}$ and electrical conductivity (EC) may show the impact of wastewater release on soil and water quality. Soil organic matter is a principal component of soil and is the key indicator of soil quality and health (Farquharson et al. 2003). Organic carbon has many positive impacts on soil fertility and greenhouse gas emission reduction (Post and Kwon 2000). Although the original source of soil and water $\mathrm{OC}$ is mainly natural (i.e. plant material), anthropogenic activities such as agricultural activities and waste disposal are other additional sources.

Phosphorus is the most limiting factor for algae, and plant growth in aquatic ecosystems and its excess amount in water resources can lead to OC production and water pollution by eutrophication. When a significant amount of $P$ reaches water bodies, eutrophication can occur which in turn depletes dissolved oxygen. Phosphorus in soil and water ecosystems comes from both pedogenic and anthropogenic sources like inorganic and organic fertilizers, crop residues, and waste (Vadas et al. 2015).

Soil $\mathrm{pH}$ influences plants directly due to its effects on nutrient solubility and availability in the soil and water environments. Salinity, assessed in soil via EC, is one of the most important factors in agriculture and irrigation management. The increase of soil salinity may lead to aggregation of soil particles, but due to the increase in osmotic potential, it reduces the absorption of water and nutrients by plants from the soil (Gawel 2009; Pisinaras et al. 2010). According to Grischek et al. (2002) increasing urbanization and developing urban centers

\section{KEYWORDS}

Agriculture, geostatistic, salinity, soil $\mathrm{pH}$, wastewater.

PALABRAS

CLAVE

Agricultura, geoestadística, salinidad, $\mathrm{pH}$ del suelo, aguas residuales.

\section{PALAVRAS-}

CHAVE

Agricultura, geoestatística, salinidade, $\mathrm{pH}$ do solo, águas residuais. 
along rivers (to provide drinking water and transportation) have reduced the natural filtering capacity of river systems through channelization of headwater streams, loss of floodplains and wetlands and the regulation of flow as the undesirable consequence of dam constructions and impoundments (Grischek et al. 2002). One of the main concerns in the agriculture is controlling and decreasing soil salinity which requires careful and quantitative considerations, mapping, and architectural supervision of soil salinity (Levy et al. 2003; Mashayekhi et al. 2007; Pisinaras et al. 2010).

To comprehensively evaluate soil properties and examine the main factors that affect them, spatial mapping of soil properties is useful. Numerous researchers have used geostatistical analysis as an effective tool to forecast the soil maps of OC, TP, pH, and EC parameters (Webster and Oliver 2001; Mueller et al. 2003; MacCarthy et al. 2013; Zhang and Shao 2014; Wang et al. 2015). Past research has shown that the application of the kriging method to produce $\mathrm{EC}$ and $\mathrm{pH}$ maps is an appropriate method to study the quality of soil, sediment, and groundwater (Mashayekhi et al. 2007; Nas 2009; Pisinaras et al. 2010). The ordinary kriging technique has been used to evaluate soil OC and soil P saturation (Sarangi et al. 2005; Mishra et al. 2009). Corstanje et al. (2006) used geostatistical methods to study spatial variability, distribution, and uncertainty assessment of soil total P (TP) in a South Florida wetland (Corstanje et al. 2006). The identification of pollutant sources and their impacts on soil and sediment quality is fundamental to control contamination and achieve sustainable development. Environmental pollutants vary over time across different locations; thus, the study of their temporal and spatial variabilities is vital (Boukhalfa and Chaguer 2012; Sakan et al. 2013).

The Meyghan Playa is the biggest natural saline water in Markazi Province, Iran (Zamani 1999). The lake covers an area of $110 \mathrm{~km}^{2}$, with the mean water depth of $1.5 \mathrm{~m}$. It is mainly used by wild animals and immigrant birds. Since rapid industrial and urban developments in the region, large amounts of wastewater from industrial, domestic and agricultural sources originating from Arak city have been released into the lake.
There are several pollution sources around the region such as seasonal rivers, municipal wastewater inputs, a sodium sulfate factory nearby and some industrial zones that discharge their entire waste into this place, which can adversely impact soil and sediments properties of the studied area. Since research about soil properties distribution in soil and sediment is helpful and provides valuable information about their contamination and potential environmental risks, the purpose of this study was to achieve an overview of some quality properties of present soil and sediment in the Meyghan Playa based on the spatial distribution of OC, TP, pH, and EC using geostatistical methods for investigating their possible origins and changes by geogenic and/or anthropogenic impacts. The study of the spatial distribution and interpolation maps of $\mathrm{OC}, \mathrm{TP}, \mathrm{pH}$, and EC and overlaying them with maps of land use and parent material, may reveal geogenic and/or anthropogenic impacts. The results of this research could be used to enhance the water and soil management of the Meyghan Playa and will be beneficial for researchers and managers seeking to improve water and wastewater management.

\section{Materials and methods}

\subsection{Study area}

The study area, the Meyghan Playa, is placed in the north of Arak city in the southern region of Markazi Province, Iran (Zamani 1999; Ghadimi 2014). The area covers approximately 52,480 hectares located between latitudes $34^{\circ} 06^{\prime}-34^{\circ} 19^{\prime} \mathrm{N}$ and longitudes $49^{\circ} 42^{\prime}-49^{\circ} 57^{\prime} \mathrm{E}$ in northwestern Iran (see Figure 1). The water of the Meyghan Lake is fed by the Gharakahriz and Ashtian ephemeral streams. Many minor streams from the Farmahin, Amanabad, and Haftadgholeh areas feed the playa. In addition, the wastewater of a sodium sulfate factory in the southern part of the lake, the wastewater of some industrial areas surrounding this region, and municipal wastewater of Arak city are discharged directly into this lake. The average 
wastewater depth is approximately $0.5 \mathrm{~m}$ with a maximum depth of about $1.5 \mathrm{~m}$. Despite a large catchment zone, the Meyghan Playa has been receiving very limited natural water in recent years mainly due to present arid climatic conditions. The surface of the Meyghan Playa desiccates every summer forming a saline crust. This crust essentially consists of gypsum, glauberite, halite, and calcite (Zamani 1999). The playa catchment is located in a semi-arid zone. The annual average air temperature of Arak city is $13.8^{\circ} \mathrm{C}$ while its annual rainfall is $315 \mathrm{~mm}$. Figure 1 shows a sketch map of the studied area location and sampling points.

\subsection{Sampling and analysis}

In August 2013, soil samples were collected from 250 sites while using global positioning system (GPS) to record the locations around the Meyghan Playa from the surface soil layer at depths $0-30 \mathrm{~cm}$ (top soil). We tried to sample randomly from the sites; however, more samples were taken in the areas with high spatial variabilities. During the sampling phase, the researchers faced areas around the lake which were submerged; therefore, a linear transect was performed for sampling the sediments (e.g., at the southwestern shoreline to the center of the lake). All samples were put in plastic bags
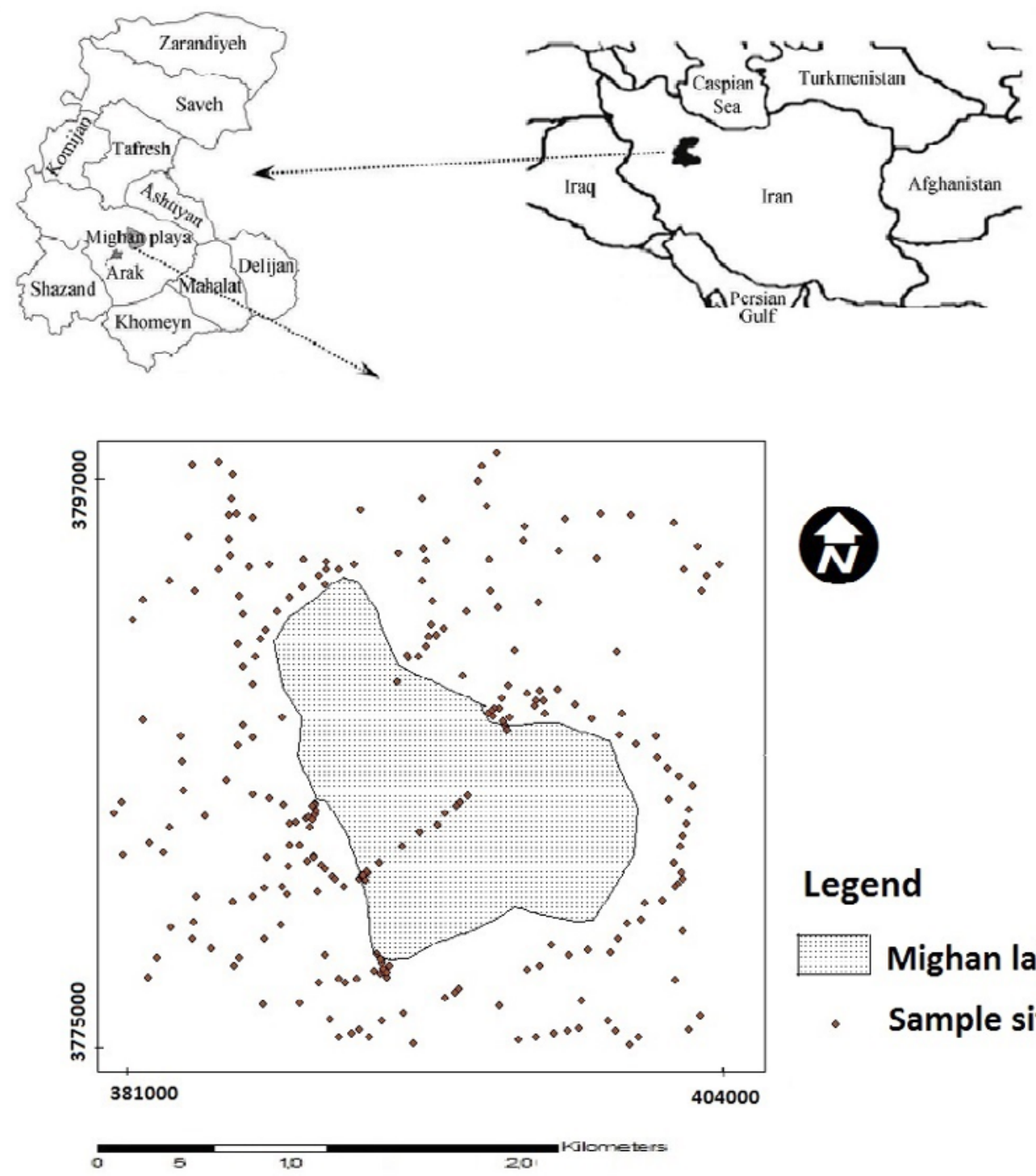

\section{Legend}

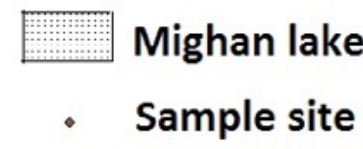

Figure 1. The map of Iran, Markazi province with Meyghan Playa in Arak city and the sampling points. 
and were taken to the laboratory. The samples were air dried for several days at $25^{\circ} \mathrm{C}$ and sieved with a $2 \mathrm{~mm}$ sieve prior to the analysis. The $\mathrm{EC}$ and $\mathrm{pH}$ were determined in the extract of $1: 5$ soil: water after shaking for 30 minutes (Hesse 1971). Soil OC was measured by the ferrous ammonium sulfate method (Walkley and Black 1934). Soil TP was assessed after digestion in $4 \mathrm{~N} \mathrm{HNO}_{3}$ according to the method of (Sposito et al. 1981), and then it was determined spectrophotometrically as blue molybdatephosphate complexes under partial reduction with ascorbic acid (Jackson 1958).

\subsection{Data analysis}

Outlier data were identified based on the Doerffel method (Doerffel 1967) and were replaced with with maximum acceptable value remaining after deleting the outliers (Hassani Pak and Sharafdin 2001). The kriging analysis and variogram require a normal data distribution. The Kolmogorov-Smirnov method was used for the evaluation of data, and non-normal distribution was normalized before statistical analysis by applying the Box-Cox transformation using IBM SPSS Statistics 20 software.

Mapping of soil properties is the initial step for proper monitoring and soil management. In the present study, the ordinary kriging method gave useful results for the estimation of parameters regarding the lowest statistical error indices. Hence, it was used for the estimation and mapping of soil properties at unsampled places. Due to the non-normal distribution, the log-transformed data for soil OC and Cox-Box transformed data for $\mathrm{EC}$ and $\mathrm{pH}$ were used for kriging interpolation and then the estimated amounts were back-transformed.

\subsection{Geostatistical Analysis}

Geostatistical methods were used to estimate soil OC, TP, pH, and EC for mapping and studying their spatial distributions in the region. The semivariogram method was applied to survey discrete soil samples. Each semivariogram model can be explained using components of nugget variance, sill, and range.
The semivariogram is estimated using the following equation:

Eq. $1 \quad \gamma(\mathrm{h})=\frac{1}{2 \mathrm{~N}(\mathrm{~h})} \sum_{\mathrm{i}=1}^{\mathrm{N}(\mathrm{h})}\left[\mathrm{Z}\left(\mathrm{x}_{\mathrm{i}}\right)-\mathrm{Z}\left(\mathrm{x}_{\mathrm{i}}+\mathrm{h}\right)\right]^{2}$

where $N(h)$ is the total data pairs number that separated with a distance $h ; Z$ is the calculated amount for the property of soil and $x$ is the location of soil samples.

According to Shi et al. (2007), different standard models such as exponential, Gaussian, linear, and spherical models are available to match the experimental semivariogram. At first, in order to determine if the semivariogram functions depended on the sampling orientation and direction, the anisotropic distributions were computed in four directions of $0^{\circ}, 45^{\circ}, 90^{\circ}$ and $135^{\circ}$ with a tolerance of $22.5^{\circ}$. The calculation of variograms in different directions did not show any difference in spatial dependence based on direction. Therefore, isotropic semivariogram was selected for each variable. The model parameters such as nugget, range, sill, and residual sum of square (RSS) and the coefficient of determination $\left(\mathrm{r}^{2}\right)$ were obtained with GS+ 5.3 gamma design software. RSS and $r^{2}$ indicate the best semivariogram model. The model with the highest $r^{2}$ and the lowest RSS values was selected. The degree of spatial dependence was computed based on the ratio of noise (nugget variance) to sill (total variance) multiplied by 100 .

\subsection{Interpolation methods}

Among interpolation methods, kriging is a key tool in geostatistics. Kriging is the best linear unbiased prediction of the intermediate values. Kriging estimates of soil OC, TP, $\mathrm{pH}$, and EC were computed as the weighted average of the known values of the function in the neighborhood of the sample. Kriging is a kind of weighted moving average that is considered as a good interpolation method of spatial interpolation (Krige 1951):

Eq. $2 \quad \hat{z}\left(x_{0}\right)=\sum_{i=1}^{n} \lambda_{i} z\left(x_{i}\right)$ 


\section{Results}

where $\hat{z}\left(X_{0}\right)$ is the estimated parameters at the location of $x_{0} ; z\left(x_{i}\right)$ is the known parameter at the sample location $x_{i}$, and $n$ is the number of locations within the search neighborhood applied for the estimation.

In this study, ordinary kriging was applied to accurately estimate the behavior of a predictive model. Statistical indices of mean prediction error (MPE), root mean square prediction error (RMSPE), average kriging standard error (AKSE), mean standardized prediction error (MSPE), and root mean square standardized prediction error (RMSSPE) were used for OC, TP, $\mathrm{pH}$, and EC calculated via GIS software.

The best models of experimental semivariance were obtained by GS+ 5.3 gamma design and kriging was calculated using the Geostatistical Analyst extension of ArcGIS 9.3 Esri. The interpolated distribution map of $\mathrm{OC}, \mathrm{TP}, \mathrm{pH}$, and EC were prepared using GIS Esri software. To reveal the most important factors affecting these properties, the interpolated distribution maps of the studied soil properties, land use, river and road maps were overlapped separately with the layers of the map in GIS system and geological maps.

\subsection{Descriptive statistics}

The evaluation of data is an essential prerequisite of selecting the suitable method for the geostatistical analysis. First, the outliers were checked. Only one $\mathrm{pH}$ value was identified as an outlier and replaced with the maximum acceptable value. The descriptive statistics of soil properties are reported in Table 1. The coefficient variation $(\mathrm{CV})$ values for the studied soil properties ranged from 0.04 to 2.4. The highest CV belonged to EC (2.4), suggesting that the EC of the 1:5 soil extract has the maximum change between the other studied soil parameters. It ranged from 0.1 to $97 \mathrm{dS} \mathrm{m}^{-1}$, likely being influenced by external parameters such as climatic conditions or anthropogenic sources. The CVs for soil OC and TP were 0.65 and 0.48 , respectively. We expected that the soil TP would have a higher $\mathrm{CV}$, but the variability of this soil property was lower than that of OC. The studied soils had low OCs with the mean of $0.8 \%$ due to arid conditions where $\mathrm{OC}$ inputs are low and outputs are high. The range of soil OC contents was between 0.1 and $3.45 \%$. The $\mathrm{CV}$ value for $\mathrm{pH}$ was the lowest (0.04), ranging from 7.6 to 9.14 with a mean of 8.1. Although

Table 1. Descriptive statistical parameters and Kolmogorov-Smirnov test of normality (K-S) for soil organic carbon (OC), total phosphorus (TP), pH and electrical conductivity (EC) in Meyghan Playa, Iran

\begin{tabular}{|c|c|c|c|c|c|c|c|}
\hline & Range & Mean & $\mathrm{SD}^{\mathrm{a}}$ & $\mathrm{CV}^{\mathrm{b}}$ & Kurtosis & Skewness & $\begin{array}{l}\text { (K-S test) } \\
(\mathrm{P}>0.05)\end{array}$ \\
\hline OC (\%) & $0.1-3.49$ & 0.8 & 0.53 & 0.65 & 7.76 & 2.41 & 0 \\
\hline $\log O C$ & $-2.3-1.25$ & -0.34 & 0.56 & - & 1.14 & -0.11 & 0.38 \\
\hline $\mathrm{TP}\left(\mathrm{mg} \mathrm{kg} \mathrm{kg}^{-1}\right)$ & $15.4-656$ & 244 & 118 & 0.48 & 0.48 & 0.5 & 0.35 \\
\hline $\mathrm{pH}$ & $7.6-9.14$ & 8.1 & 0.3 & 0.04 & 3.3 & 0.77 & 0 \\
\hline Box-Cox pH & $0.86-0.89$ & 0.87 & 0.005 & 0.005 & 0.4 & 0.14 & 0.11 \\
\hline $\mathrm{EC}\left(\mathrm{dS} \mathrm{m}^{-1}\right)$ & $0.1-97$ & 5.6 & 13.5 & 2.4 & 20.5 & 3.9 & 0 \\
\hline Box-Cox EC & $-3.3-2.4$ & -0.12 & 1.3 & - & -0.97 & 0.07 & 0.12 \\
\hline
\end{tabular}

a- SD: Standard deviation; b- CV: Coefficient variation. 
the variability of this soil property was low, the distribution of its measured data was not normal.

The Kolmogorov-Smirnov test for soil properties showed that only TP had a normal distribution $(p>0.05)$. The distributions of $\mathrm{OC}, \mathrm{pH}$, and EC were not normal. Although the skewness and kurtosis values for $\mathrm{pH}$ data were low (0.77 and 0.33 , respectively), its standard deviation and CV were extremely low; thus, it did not have a normal distribution in the Kolmogorov-Smirnov test. The raw dataset of OC was logarithmically transformed and the raw datasets of $\mathrm{pH}$ and EC were transformed by the Box-Cox method. These transformations resulted in the reduction of the skewness and kurtosis in addition to the normal distribution for the converted data. The ranges, mean values, standard deviations, coefficients of variation, Kurtosis, Skewness, and $p$-values of Kolmogorov-Smirnov test for each variable are presented in Table 1.

\subsection{Geostatistical analysis}

The model parameters for each semivariogram are presented in Table 2. Figure 2 shows the semivariogram and fitted model for soil OC, TP, $\mathrm{pH}$, and EC. The results for random variability in the descriptive analysis of the studied soil properties were different compared to the semivariance at $h=0$ (nugget variance). In the descriptive analysis, soil EC showed the highest CV (2.4) and a high SD (13.5), whereas the CVs for soil OC and TP were lower (0.65 and 0.48, respectively). Here in the geostatistical analysis as we expected, soil TP had the highest nugget variance (8830), which was much larger than those for the other soil properties. The nugget variance for soil $\mathrm{OC}$ and $\mathrm{EC}$ were noticeably low (0.14 and 0.48 , respectively). The nugget variance for $\mathrm{pH}$, similar to its variability indices in descriptive analysis, was the lowest one (0.00002).

The nugget to sill ratio (NSR) for the spatial tendency of soil EC was less than $25 \%$; therefore, according to Cambardella et al. (1994), it can be concluded that soil EC had strong spatial dependence. The nugget to sill ratio (NSR) for soil OC, TP, and $\mathrm{pH}$ was between $25 \%$ and $75 \%$, so these variables were considered as moderately spatially dependent. The nugget effect can be an indicator of the continuity at close distances, and soil properties with lower nugget effects were generally defined better by a spherical semivariogram model. In our study, the results showed that soil $\mathrm{OC}, \mathrm{pH}$, and $\mathrm{EC}$ data matched to the spherical model, and TP matched to the exponential model. The range for TP was the highest one (49950 m), but on the other hand, the ranges for OC and EC (2490 and $3830 \mathrm{~m}$, respectively) were lower than those for the other soil properties (Table 2).

Table 2. Parameters of the theoretical models fitted to the experimental variograms for soil organic carbon $(\mathrm{OC})$, total phosphorus (TP), $\mathrm{pH}$ and electrical conductivity (EC) in Meyghan Playa, Iran

\begin{tabular}{lcccccccc} 
Variable & Model & $\begin{array}{c}\text { Nugget } \\
\text { Effect (N) }\end{array}$ & Sill (S) & $\begin{array}{c}\text { N/S Ratio } \\
(\%)\end{array}$ & $\begin{array}{c}\text { Spatial } \\
\text { dependency }\end{array}$ & $\begin{array}{c}\text { Effective } \\
\text { Range }(\mathbf{m})\end{array}$ & RSS $^{\mathbf{2}}$ & $\mathbf{R}^{2}$ \\
\hline OC & Spherical & 0.1392 & 0.327 & 42.57 & Moderate & 2490 & 0.002 & 0.903 \\
\hline TP & Expotential & 8830 & 30160 & 29.28 & Moderate & 49950 & $1.20 \mathrm{E}+07$ & 0.82 \\
\hline pH & Spherical & 0.00002 & 0.00004 & 50.00 & Moderate & 5230 & $9.00 \mathrm{E}-11$ & 0.824 \\
\hline EC & Spherical & 0.477 & 1.92 & 24.84 & Strong & 3830 & 0.107 & 0.927 \\
\hline
\end{tabular}

a- RSS: residual sum of square. 

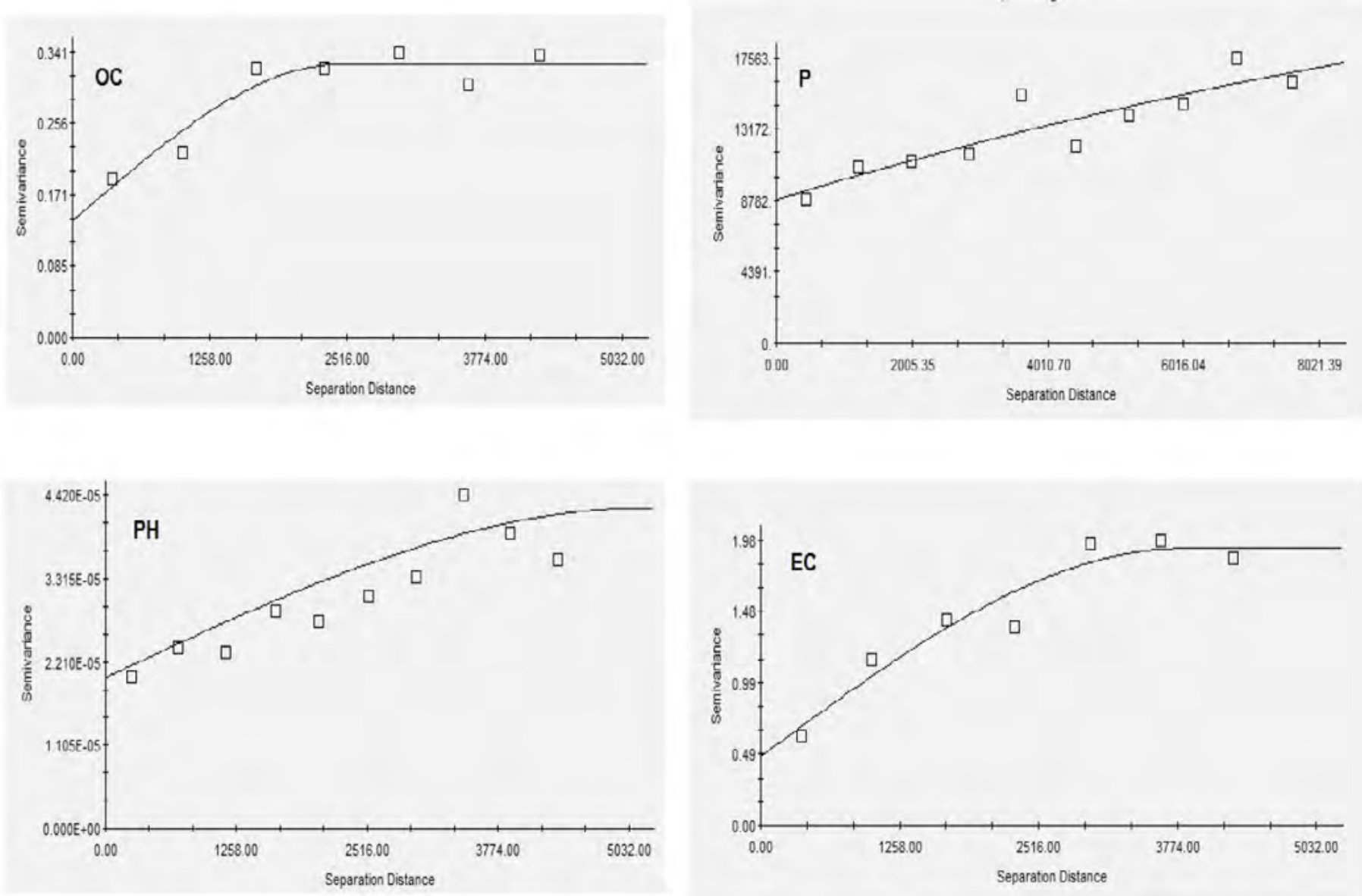

Figure 2. The semivariogram graph for soil organic carbon (OC), total phosphorus (TP), pH and electrical conductivity (EC) in Meyghan Playa, Iran.

3.3. Estimating and mapping the studied soil properties

The parameters of optimal kriging were determined using the results of the crossvalidation. The prediction errors were reported in Table 3. They were very low and acceptable. The estimation errors for $\mathrm{pH}$ and $\mathrm{OC}$ were remarkably lower than those for soil TP and EC. The maps for soil OC, TP, pH, and EC were prepared using an extension of spatial analyst by ArcGIS 9.3 software (Figure 3 and Figure 4 ). In the current research, the studied soil properties were mapped for unsampled places. The maps showed different patterns of spatial distribution for the studied soil properties due to the intrinsic and extrinsic variables and nature of that soil property. Properties with a strong spatial dependence like soil EC may be influenced by the inherent characteristics of soil such as mineralogy, texture, and hydrology. External variables, such as wastewater and fertilizer use and tillage, may influence the variability of weakly spatially dependent soil properties (OC, TP, and $\mathrm{pH})$. In this research, TP had the lowest spatial dependence among the other soil properties. 
Table 3. Cross validation results and errors in prediction of soil organic carbon (OC), total phosphorus (TP), $\mathrm{pH}$ and electrical conductivity (EC) in Meyghan Playa, Iran.

\begin{tabular}{cccccc} 
Variable & \multicolumn{5}{c}{ Prediction Errors } \\
& ME & RMSE & ASE & MSE & RMSSE \\
\cline { 2 - 6 } OC & 0.007 & 0.402 & 0.424 & 0.007 & 0.99 \\
\hline TP & 0.01 & 96.12 & 97.88 & -0.0009 & 0.99 \\
\hline pH & 0.008 & 0.25 & 0.3 & 0.02 & 0.72 \\
\hline EC & -0.0001 & 11 & 10 & -0.5 & 1.2
\end{tabular}

ME: Mean Error, RMSE: Root Mean Square Error, ASE: Average Standard Error, MSE: Mean Standardized Error, RMSSE: Root Mean Standardized Error.
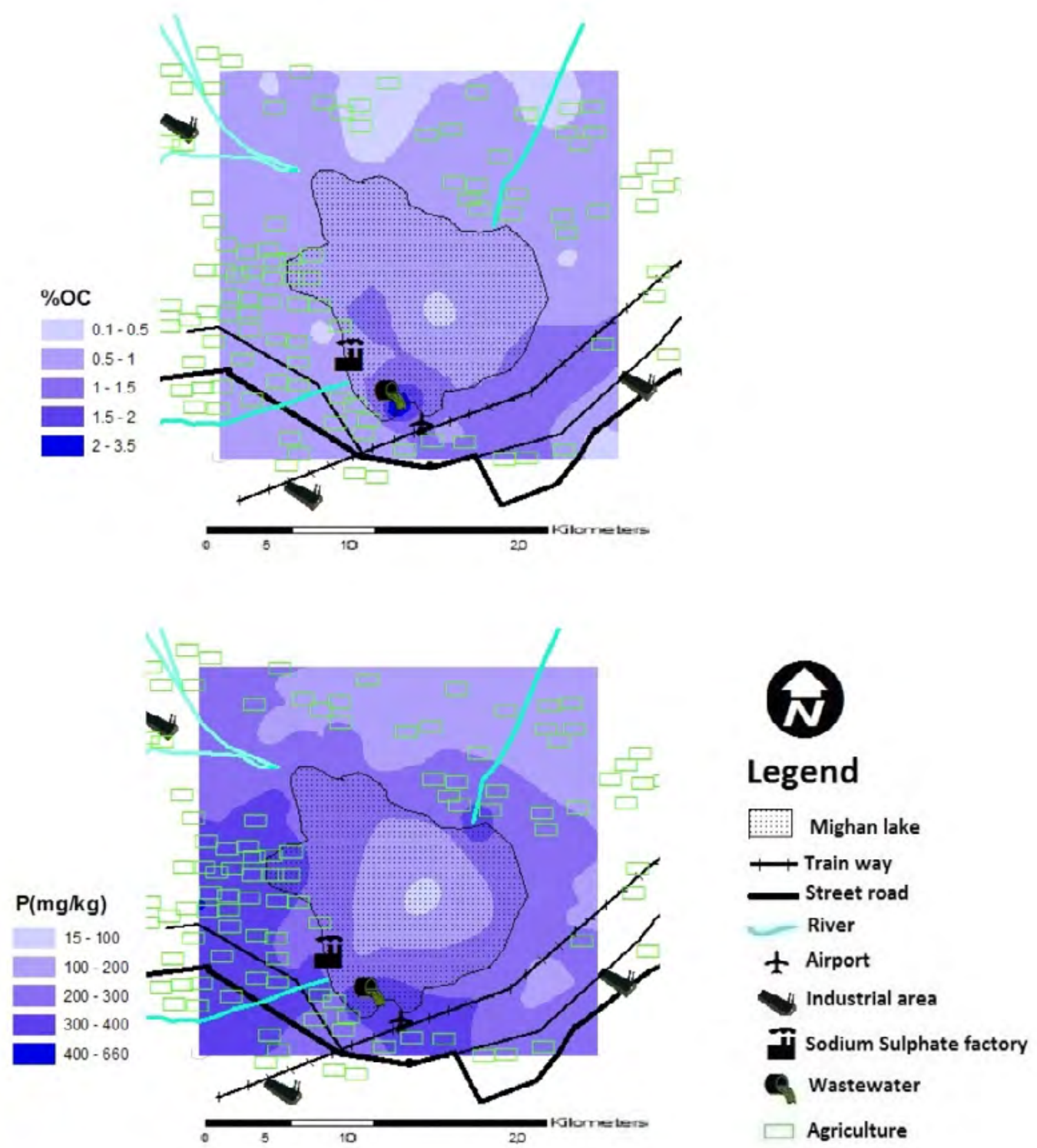

Figure 3. The interpolation maps of soil organic carbon (OC) and total phosphorus (TP) in Meyghan Playa, Iran, produced by ordinary kriging. 
3.4. The distribution and possible origin of the studied soil properties

\subsubsection{Soil organic carbon and total phosphorus}

The maximum amounts of OC (more than $2 \%$ ) and $\mathrm{P}$ (more than $400 \mathrm{mg} \mathrm{kg}^{-1}$ ) in the studied area have been observed near municipal wastewater entrance (see Figure 3). Many studies have shown the accumulation of organic matter and $\mathrm{P}$ due to wastewater release into soil and water (Mohammad and Mazahreh 2003; Nhapi 2004). In addition, large amounts of $P$ were also found in agricultural lands in the eastern and southeastern parts of the lake near Arak city.

\subsubsection{Soil $\mathrm{pH}$ and $\mathrm{EC}$}

All of the sampled soils had an alkaline $\mathrm{pH}$ ranging between 7.6 and 9.1 (mean $=8.1$ ) for $1: 5$ soil: water extracts. Figure 5 shows the geological map of the Meyghan Playa. The presence of alkaline cations and salts, especially limestone in parent material, in addition to the transported soluble salts are the main causes of alkaline $\mathrm{pH}$ in this region (see Figure 4). The spatial models of $\mathrm{EC}$ and $\mathrm{pH}$, evaluated with kriging especially $E C$, illustrate the high dependence from the slope. The maximum $\mathrm{pH}$ (more than 8.5 ) and EC $\left(64 \mathrm{dS} \mathrm{m}^{-1}\right)$ in this region were found in the central parts of the lake (see Figure 4).
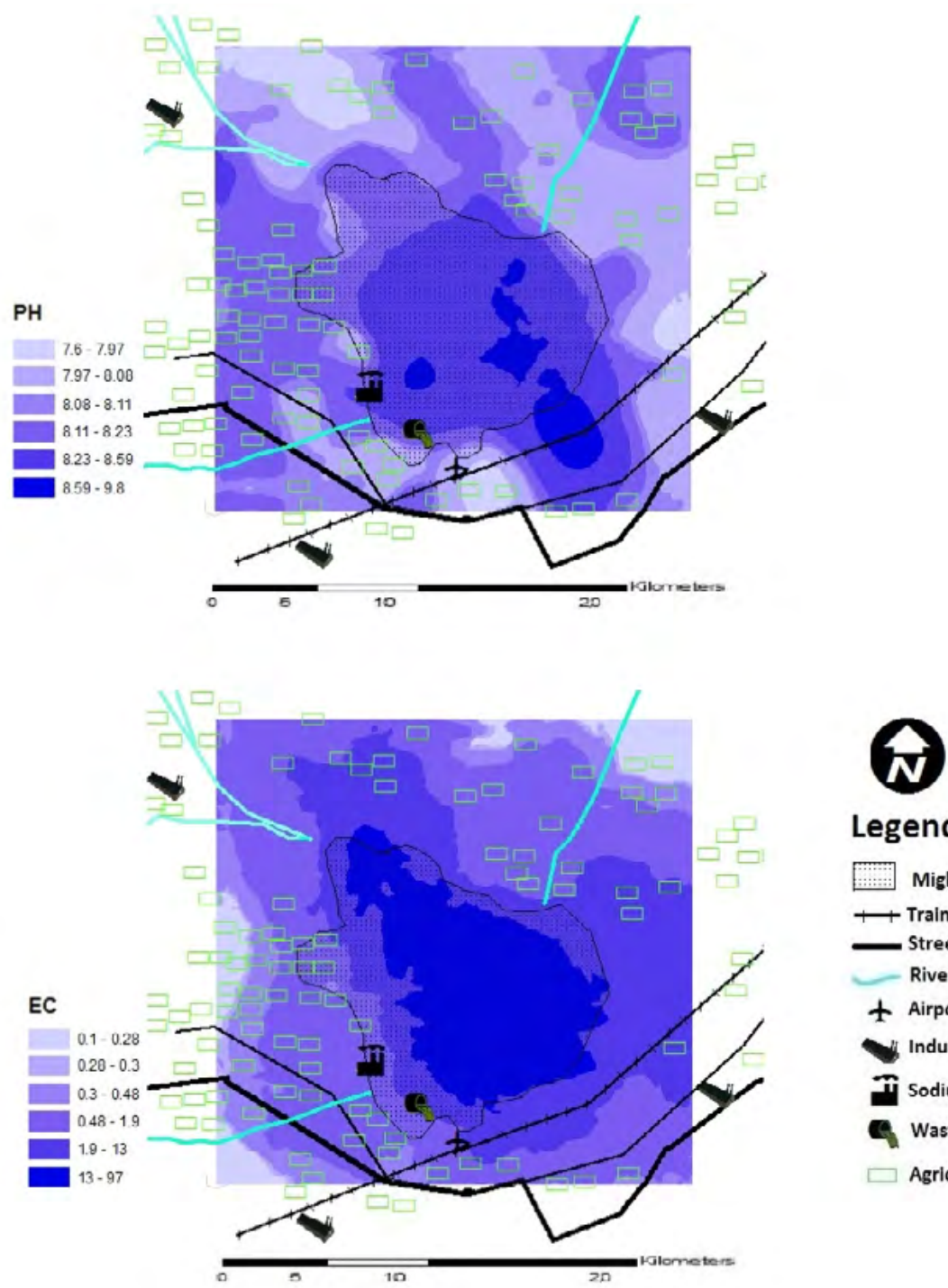

Legend

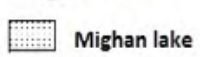

廿 Train way

Street road

River

+ Airport

Industrial area

Ty Sodium Sulphate factory

Wastewater

$\square$ Agriculture

Figure 4. The interpolation maps of soil $\mathrm{pH}$ and electrical conductivity $\left(\mathrm{EC}, \mathrm{dS} \mathrm{m}^{-1}\right)$ in Meyghan Playa, Iran, produced by ordinary kriging. 


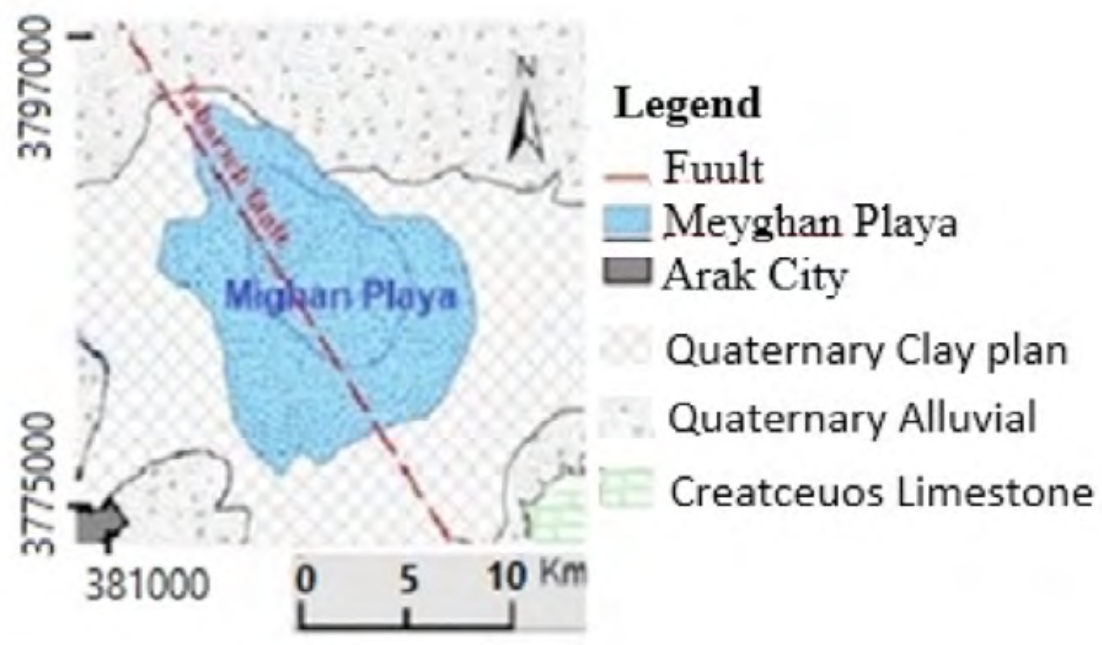

Figure 5. The geological map of the sudied area in Meyghan Playa, Iran (Gadimi and Ghomi 2013).

\section{Discussion}

In the present study, the smallest range was obtained for OC and the second smallest for EC as mobile and variable soil properties. In turn, for the presumably least mobile soil properties $\mathrm{pH}$ and specially soil TP, spatial correlations were observed across the longer distances.

The spatial dependencies and ranges for each of the studied soil properties were very long compared to those reported by others. The spatial distribution of total OC and nitrogen of soil had moderate gradients in a small watershed in a Hilly area of Northern China (Peng et al. 2013). Wang et al. (2015), using the NSR, reported that many of the soils studied parameters had a moderate spatial dependency. In depth of $0-20 \mathrm{~cm}$, a strong spatial dependency was obtained for soil total nitrogen, but the NSR for topsoil OC was $53.6 \%$, and it had a moderate spatial dependency. The spatial dependency of nearsurface soil $\mathrm{OC}, \mathrm{pH}$ and, EC were moderate in the urban-mining transitional region in Isfahan, Iran (Dayani et al. 2010).

The results indicated that soil $\mathrm{OC}, \mathrm{pH}$ and $\mathrm{EC}$ data matched the spherical model, and TP matched the exponential model. Semivariogram analysis showed that $\mathrm{pH}$ and $\mathrm{EC}$ had a spherical model in agricultural fields of Golestan Province (Kazemi Poshtmasari et al. 2012). Similarly, the study of the spatial variability of soil OC in Jiangsu Province, China showed a spherical model for the soil OC (Xiao-Wei et al. 2012). The investigation of the distribution of soil $P$ in a South Florida wetland revealed that the spherical model was the best model among others (Grunwald et al. 2004).

The distribution and possible origin of $\mathrm{OC}$ and $P$ in soil and sediment are discussed in the following. Domestic wastewater contains compounds including nutrients and organic matter that, if not properly treated, can increase water eutrophication, alter the ecological balance of water systems, threaten aquatic organisms, and risk public health (Gulati and Van Donk 2002). Nhapi (2004) reported that Chivero Lake in Zimbabwe is hypertrophic and has unsatisfactory conditions. Arak municipal wastewater is the main source of nutrients in the Meyghan Lake. Flooding and salinity can reduce the activity of heterotrophic organisms and organic matter decomposition, leading to accumulation of $\mathrm{OC}$ in the place of municipal wastewater entrance. Salt marshes may have a new layer of soil organic matter due to greater input than output (Kirwan and Megonigal 2013). Faster decomposition rates in fresh marshes than brackish and salt marshes have been reported (Nyman and DeLaune 1991). Organic 
compounds in soil with high levels of sodium are more sensitive to losses in dissolved or colloidal forms, due to decreased bindings to soil minerals (Peinemann et al. 2005; Mavi et al. 2012). This condition can help to transfer $\mathrm{OC}$ to the lake and contaminate the lake water. Dissolved OC can be lost going from the soil through runoffs and leaching into surface water and groundwater, leading to harmful effects on the quality of water (EPAAustralia 1998; Stevenson and Cole 1999).

According to our analysis, the secondary effluent of municipal wastewater of Arak city is discharged daily (at a rate of $700 \mid \mathrm{s}^{-1}$ ) with a high level of $P\left(5.4 \mathrm{mg} \mathrm{l}^{-1}\right)$ into the Meyghan Lake. Annually, 22.07 million $\mathrm{m}^{3}$ of municipal wastewater with $119,178 \mathrm{~kg} P$ are added to the lake. This input of $P$ from urban and agricultural wastewater into the Meyghan Playa increases the risk of pollution extending to the lake leading eutrophication. The rate of nutrient entry increase in the Meyghan water with fast industrialization and urbanization of Arak city has increased the soil OC and TP in the southern parts of the lake and the entrance of wastewater to the Meyghan Lake. The extreme amounts of $P$ and other elements such as nitrogen or potassium poured into the water by Arak municipal wastewater could have serious ecological consequences on the salty aquatic ecosystem of the Meyghan Playa. The rapid growth of algae and aquatic plant can adversely impact the quality of water (Western 2001; Sharpley et al. 2015).

In addition to the entrance of wastewater, soil TP in the studied area was also high in agricultural lands near Arak city and the Farahan river mouth. In fact, the application of $P$ fertilizer leads to its accumulation in soils (Western 2001; Gulati and Van Donk 2002; Ebbers et al. 2015). Our findings showed that the application of excessive $P$ fertilizers for vegetable farming in agricultural lands near Arak city resulted in $P$ enrichment. Histories of long-term management of farming activities should be well known because farming operations can affect the spatial distribution and the level of spatial dependence of soil parameters. In addition, the soluble and clay-adsorbed $\mathrm{P}$ can be transported from upland areas toward lowland areas by the rivers, groundwater, and runoffs (Bennett et al. 2001; Hahn et al. 2012). Excessive applications of $P$ fertilizers in agricultural lands cause their enrichment in soils, which in turn leads to more $\mathrm{P}$ carried into streams and lakes via surface runoffs and macropore flow. Nitrogen and $P$ losses from agricultural systems via surface runoffs have been identified as non-point pollution sources; hence, there is a need to accurately quantify the runoff nutrient loss from farms and develop management practices to reduce that loss (Vadas et al. 2015).

In addition, using fertilizers in agricultural lands can increase soil $\mathrm{pH}$ and EC. Excessive fertilizer application can increase soil salinity (Whiting et al. 2015) and should be precisely monitored, especially on sites with potential salinity concerns. This condition with poor infiltration, poor drainage, saturated soil, or compaction that lead to the capillary rise of saline, sodic groundwater can increase soil EC and $\mathrm{pH}$. When the water table is within a few meters of the soil surface, the capillary rise of saline groundwater will transport salts to the soil surface. This process is more intense in arid regions because of high levels of water evaporation. The water evaporation in this arid region is estimated to be four times its annual rainfall. The surface of the Meyghan Playa undergoes desiccation every summer. Salts from uplands dissolve when they come in contact with fresh runoff during winter, and this process increases the solute load of the Meyghan Lake. The chemical composition of its salty water is known to be particularly high in calcium and sodium. Sodium and calcium sulfates and sodium chloride are the main salts of the lake water in the Meyghan Playa (Zamani 1999; Ghadimi and Ghomi 2013; Ghadimi 2014).

Many researchers have reported that using treated wastewater can increase soil salinity. Soil EC (salinity) significantly increases but $\mathrm{pH}$ does not significantly decrease by irrigation with wastewater (Panahi Kordlaghari et al. 2013). In our study, we have found that the discharge of Arak municipal wastewater in the Meyghan Playa had no considerable effects on soil and water $\mathrm{pH}$ and EC (Figure 4). The spatial distributions of $\mathrm{pH}$ and $\mathrm{EC}$ in the studied soils naturally depend on intrinsic pedogenic factors. Where carbonate is present in soils, as it is common in calcareous parent materials (e.g., limestone or dolomite), the soils will usually be slightly or even strongly alkaline in character (Gray and Murphy 2002). The Meyghan Playa hydrology 
is governed by a complex interaction between geology, topography, and climate. They are the natural factors controlling soil and water acidity and salinity ( $\mathrm{pH}$ and $\mathrm{EC})$ in this region. However, the spatial distribution and variability of $\mathrm{OC}$ and TP in soil depend on external agents like the land use and resource management strategies. In summary, $\mathrm{pH}$ and EC in this area are more controlled by geogenic factors, but the variability of OC and TP in the soil are associated with anthropogenic impacts.

\section{Conclusions}

1) There was a strong spatial variability in the Meyghan Playa soil EC levels and a moderate spatial variability in the soil OC, TP and $\mathrm{pH}$.

2) Geostatistical analysis and kriging were useful for estimating the amounts of OC, TP, $\mathrm{pH}$, and $\mathrm{EC}$ of soil and for explaining the spatial variability. A considerable heterogeneity of these variables was seen from the maps.

3) The spatial distributions of $\mathrm{pH}$ and $\mathrm{EC}$ in the studied soils depend on intrinsic geologic and pedogenic factors. However, the spatial distribution and variability of soil $\mathrm{OC}$ and TP were mainly governed by extrinsic factors such as land use, discharge of wastewater, and resource management strategies.

4) Further monitoring of soil properties is necessary to evaluate the impact of the anthropogenic activities on the environment of the Meyghan Playa, Arak city based on geostatistical methods.

\section{Acknowledgements}

This study was supported by funds allocated by the Vice-President for Research of Bu-Ali Sina and Arak University. The authors acknowledge the assistance and help of Mr. Panahi in Bu-Ali Sina University for some laboratory analyses.

\section{REFERENCES}

- Bennett EM, Carpenter SR, Caraco NF. 2001. Human impact on erodable phosphorus and eutrophication: A global perspective. Bioscience 51: 227-234.

- Boukhalfa C, Chaguer M. 2012. Characterisation of sediments polluted by acid mine drainage in the northeast of Algeria. Intern J Sediment Res. 27:402-407.

- Cambardella CA, Moorman TB, Novak J, Konopka AE. 1994. Field-scale variability of soil properties in Central lowa Soils. Soil Sci Soc Am J. 58:1501-1511.

- Corstanje R, Grunwald S, Reddy KR, Osborne TZ, Newman S. 2006. Assessment of the spatial distribution of soil properties in a northern everglades marsh. J Environ Quality 35:938-949.

- Dayani M, Mohammadi J, Naderi Khorasgani M. 2010. Geostatistical assessment of $\mathrm{Pb}$ and the related soil physical and chemical properties in near-surface soil around Sepahanshahr, Isfahan. Desert 15:139-149.

- Doerffel K. 1967. Handbuch Lebensmittelchemie. Berlin Heidelberg: Springer.

- Ebbers B, Ottosen LM, Jensen PE. 2015. Electrodialytic treatment of municipal wastewater and sludge for the removal of heavy metals and recovery of phosphorus. Electrochimica Acta 181:90-99.

- EPA Australia. 1998. Adelaide, Australia: Environment Protection Agency.

- Farquharson RJ, Schwenke GD, Mullen JD. 2003. Should we manage soil organic carbon in Vertisols in the northern grains region of Australia? Aust J Exp Agr. 43:261-270.

- Gawel LJ. 2009. A Guide for Remediation of Salt/ Hydrocarbon Impacted soil. Bismarck, ND: North Dakota Industrial Commission.

- Ghadimi F. 2014. Assessment of the sources of chemical elements in sediment from Arak Mighan lake. International Journal of Sediment Research 29:159-170.

- Ghadimi F, Ghomi M. 2013. Assessment of the effects of municipal wastewater on the heavy metal pollution of water and sediment in Arak Mighan lake, Iran. Journal of Tethys 1:205-214. 
- Gray J, Murphy B. 2002. Parent material and world soil distribution. In: Proceedings of the 17th WCSS; 2002 August 14-21; Thailand. p. 14-21.

- Grischek T, Foley A, Schoenheinz D, Gutt B. 2002. Current problems of hydrogeology in urban areas, urban agglomerates and industrial centres. Dordrecht, The Netherlands: Kluwer Academic Publishers.

- Grunwald S, Reddy KR, Newman S, DeBusk WF. 2004. Spatial variability, distribution and uncertainty assessment of soil phosphorus in a south Florida wetland. Environmetrics 15:811-825.

- Gulati RD, Van Donk E. 2002. Lakes in the Netherlands, their origin, eutrophication and restoration: State-of-theart review. Hydrobiologia 478:73-106.

- Hahn C, Prasuhn V, Stamm C, Schulin R. 2012 Phosphorus losses in run off from manured grassland of different soil P status at two rainfall intensities. Agriculture, Ecosystems and Environment 153:65-74.

- Hassani Pak AA, Sharafdin M. 2001. Exploratory Data Analysis. Tehran, Iran: Publishing Center Tehran University (In Persian)

- Hesse PR. 1971. A Text book of Soil Chemical Analysis. London: John Murray.

- Jackson ML. 1958. Soil Chemical Analysis. Englewood Cliffs, N.J.: Prentice-Hall, Inc.

- Kazemi Poshtmasari H, Tahmasebi Sarvestani Z, Kamkar B, Shataei S, Sadeghi S. 2012. Comparison of interpolation methods for estimating $\mathrm{pH}$ and $\mathrm{EC}$ in agricultural fields of Golestan province north of Iran. Intl J Agri Crop Sci. 44:157-167.

- Kirwan ML, Megonigal JP. 2013. Tidal wetland stability in the face of human impacts and sea-level rise. Nature 504:53-60.

- Krige D. 1951. A statistical approach to some basic mine valuation problems on the Witwatersrand. Journal of The Chemical, Metallurgical and Mining Society of South Africa 52:119-139.

- Levy GJ, Mamedov Al, Goldstein D. 2003. Sodicity and water quality effects on slaking of aggregates from semi arid soils. Soil Sci. 168:552-562.

- MacCarthy DS, Agyare WA, Vlek PLG, Adiku SGK. 2013. Spatial variability of some soil chemical and physical properties. West African Journal of Applied Ecology 21:47-61.

- Mashayekhi K, Asadi Z, Movahedi Naeini S, Hajrasuliha S. 2007. Salinity regionalization with geostatistic method in a wet soil in southern Lenjan-Isfahan iran. Indian J Agric Res. 41:1-9.

- Mavi MS, Marschner P, Chittleborough MS, Cox JW, Sanderman J. 2012. Salinity and sodicity affect soil respiration and dissolved organic matter dynamics differentially in soils varying in texture. Soil Biol Biochem. 45:8-13.
- Mishra U, Lai R, Slater F, Calhoun F, Liu D, Van Meirvenne M. 2009. Predicting soil organic carbon stock within different depth intervals using profile depth distribution functions and ordinary kriging. Soil Sci Soc Am J. 73:614-621.

- Mohammad MI, Mazahreh N. 2003. Changes in soil fertility parameters is response to irrigation of forage crops with secondary treated wastewater. Commun Soil Sci Plant Anal. 34:1281-1294.

- Mueller TG, Hartsock NJ, Stombaugh TS, Shearer SA, Cornelius PL, Barnhise RI. 2003. Soil electrical conductivity map variability in limestone soil overlain by loess. Agron J. 95:496-507.

- Nas B. 2009. Geostatistical approach to assessment of spatial distribution of groundwater quality. Pol J Environ Stud. 18:1073-1082.

- Nhapi I. 2004. Options for wastewater management in Harare, Zimbabwe. Ph.D Thesis. Wageningen University.

- Nyman JA, DeLaune D. 1991. $\mathrm{CO}_{2}$ emission and soil Eh response to different hydrological conditions in fresh, brackish, and saline marsh soils. Limnology and Oceanography 36:1406-1414

- Panahi Kordlaghari K, Nikeghbali Sisakht S, Saleh A 2013. Soil chemical properties affected by application of treated municipal wastewater. Annals of Biological Research 43:105-108.

- Peinemann N, Guggenberger G, Zech W. 2005. Soil organic matter and its lignin component in surface horizons of salt-affected soils of the Argentinian pampa. Catena 60:113-128.

- Peng G, Bing W, Guangpo G, Guangcan Z. 2013. Spatia distribution of soil organic carbon and total nitrogen based on gis and geostatistics in a small watershed in a hilly area of northern China. PLoS ONE 8:e83592.

- Pisinaras V, Tsihrintzis VA, Petalas C, Ouzounis K. 2010 Soil salinization in the agricultural lands of Rhodope district, northeastern Greece. Environ Monit Assess. 166:79-94

- Post WM, Kwon KC. 2000. Soil carbon sequestration and land-use change: Processes and potential. Glob Chang Biol. 6: 317-327.

- Sakan SM, Sakan NM, Dordevic DS. 2013. Trace element study in Tisa river and Danube alluvial sediment in Serbia. International Journal of Sediment Research 28:234-245.

- Sarangi A, Madramootoo CA, Enright P, Chandrasekharan H. 2005. Prediction of spatial variability of phosphorous over the St-Esprit watershed. Water, Air, and Soil Pollution 168:267-288.

- Sharpley AN, Lars Bergström L, Aronsson H, Bechmann M, Bolster CH, Börling K, Djodjic F, Jarvie HP, Schoumans OF, Stamm C, Tonderski KS, Ulén KS, Uusitalo R. 2015. Withers future agriculture with minimized phosphorus losses to waters: Research needs and direction. Ambio 44:163-179. 
- Shi J, Wang H, Xu J, Wu J, Liu X, Zhu H, Yu C. 2007. Spatial distribution of heavy metals in soils: A case study of Changxing China. Environ Geol. 52:1-10.

- Sposito G, Lund L, Chang A. 1981. Trace metal chemistry in arid-zone field soils amended with sewage sludge: I. Fractionation of $\mathrm{Ni}, \mathrm{Cu}, \mathrm{Zn}, \mathrm{Cd}$ and $\mathrm{Pb}$ in solid phases. Soil Sci Soc Am J. 46:260-264.

- Stevenson FJ, Cole MA. 1999. Cycles of Soil: Carbon, Nitrogen, Phosphorous, Sulfur, Micronutrients. New York: John Wiley \& Sons, Inc.

- Vadas PA, Busch DL, Mark Powell J, Brink GE. 2015. Monitoring runoff from cattle-grazed pastures for a phosphorus loss quantification tool. Agriculture, Ecosystems and Environment 199:124-131.

- Walkley A, Black IA. 1934. An examination of the Degtareff method for determining soil organic matter, and a proposed modification of the chromic acid titration method. Soil Sci. 37:29-38.

- Wang J, Yang R, Bai Z. 2015. Spatial variability and sampling optimization of soil organic carbon and total nitrogen for minesoils of the loess plateau using geostatistics. Ecological Engineering 82:159-164.

- Webster R, Oliver MA. 2001. Geostatistics for Environmental Scientists. New York: John Wiley \& Sons.

- Western D. 2001. Human-modified ecosystems and future evolution. Proceedings of the National Academy of Sciences of the United States of America 98:5458-5465.

- Whiting D, Card A, Wilson C, Reeder J. 2015. Saline soils. Colorado State University Extension 224:1-5.

- Xiao-Wei C, Xian-Jin H, Wan-Jing W, Mei Z, Li L, QiLin L. 2012. Spatial variability of soil organic carbon and related factors in Jiangsu Province, China. Pedosphere 22:404-414.

- Zamani F. 1999. Sedimentology of Arak. Mighan lake. MSc Thesis. Beheshti University. Tehran. Iran.

- Zhang P, Shao M. 2014. Spatial variability and stocks of soil organic carbon in the Gobi desert of northwestern China. PLoS ONE 94:e93584. 